\title{
Asymetria mózgu jako objaw radiologiczny pomocny w dalszej diagnostyce neurologicznej -przegląd kliniczno-radiologiczny wybranych jednostek neurologicznych związanych $z$ asymetrią budowy mózgu
}

\author{
Hemispheric asymmetry as a radiological symptom helpful in further neurological \\ diagnostics-clinico-radiological review of selected neurological units related to the \\ asymmetry of the brain structure
}

\author{
Małgorzata Jączak-Goździak* (D), Marek Stajgis** (iD) Barbara Steinborn***(D) \\ *Oddział Kliniczny Neurologii Dzieci i Młodzieży, Szpital Kliniczny im. H. Święcickiego UM w Poznaniu \\ **Katedra Radiologii Ogólnej i Neuroradiologii UM im. K. Marcinkowskiego w Poznaniu, Szpital Kliniczny im. H. Święcickiego \\ UM w Poznaniu \\ *** Katedra i Klinika Neurologii Wieku Rozwojowego UM im. K. Marcinkowskiego w Poznaniu, Oddział Kliniczny Neurologii \\ Dzieci i Młodzieży, Szpital Kliniczny im. H. Święcickiego UM w Poznaniu \\ DOI:10.20966/chn.2020.58.456
}

\section{STRESZCZENIE}

Asymetria półkul mózgu jest zjawiskiem fizjologicznym, a dominacja jednej ze stron, zwłaszcza czynnościowa, jest szczególnie wyraźna w sferze funkcji poznawczych. W odróżnieniu do fizjologicznej, w patologicznej nierówności pótkul mózgowych występują znaczne różnice w budowie anatomicznej i histologicznej oraz pojawiają się objawy takie jak niedowłady, napady padaczkowe, zaburzenia funkcji poznawczych czy zaburzenia ruchowe. W artykule przedstawiono wybrane zespoły powiązane z asymetrią półkul mózgu, dokonano klasyfikacji ze względu na etiologię oraz przebieg (na postępujące i niepostępujące), przedstawiono ich kliniczną oraz radiologiczną charakterystykę. Słowa kluczowe: asymetria pótkul mózgu, hemiatrofia, hemimegalencefalia
ABSTRACT

The asymmetry of the cerebral hemispheres is a physiological phenomenon and the dominance of one of the sides, especially the functional one, is particularly clear in the sphere of cognitive functions. In contrast to the physiological, the pathological inequality of the cerebral hemispheres shows significant differences in the anatomical and histological structure and there are symptoms such as paresis, epileptic seizures, cognitive disorders and movement disorders. The article presents selected syndromes related to the asymmetry of the cerebral hemispheres, classifies them according to their etiology and course (into progressive and non-progressive), and presents their clinical and radiological characteristics.

Key words: hemispheric asymmetry, hemiatrophy, hemimegalencephaly

\section{WSTĘP}

Asymetria półkul mózgowych jest zjawiskiem fizjologicznym i jak dowodzą współczesne badania, charakterystycznym nie tylko dla gatunku ludzkiego $[1,2]$. Już na etapie rozwoju mózgu, w życiu płodowym, zaznaczony jest moment, kiedy pojawia się nierówność półkulowa. Możliwym jej prekursorem jest, powstający w 11 tygodniu ciąży, splot naczyniówkowy [3, 4]. Dominacja jednej ze stron, funkcjonalna, ale również objętościowa, wiąże się z ręcznością i filogenetycznym nabywaniem umiejętności do życia w społeczeństwie [2]. Z tego względu, różnice między półkulami są szczególnie wyraźne w sferze funkcji poznawczych, takich jak pamięć, emocje, uwaga, język czy funkcje wykonawcze [4]. W ujęciu czynnościowym, asymetria mózgu, dotycząca prawidłowej tkanki nerwowej, jest przedmiotem zainteresowania badań neuropsychologicznych. Odmiennie, patologiczna asymetria, występuje wówczas, gdy przy znacznych różnicach anatomicznych i histologicz- nych, pojawiają się kliniczne, neurologiczne konsekwencje. Objawy strukturalnych różnic między półkulami mózgu to: niedowłady, napady padaczkowe, zaburzenia funkcji poznawczych [5] oraz zaburzenia ruchowe [6,7].

Celem tej pracy jest przedstawienie charakterystyki kliniczno-radiologicznej wybranych zespołów powiązanych ze strukturalną asymetrią mózgu.

Asymetrię mózgu, z uwagi na etiologie, można podzielić na [8]:

- hemiatrofię/hemiaplazję, gdy dochodzi do zaniku lub zatrzymania rozwoju półkuli mózgu

- wady rozwojowe kory mózgowej, gdy na skutek zaburzeń migracji neuroblastów występuje hemimegalencefalia lub hemimicrencefalia.

Przypadki z hemiatrofią mózgu grupuje się dalej: na wrodzone lub nabyte $[5,8]$ oraz z klinicznego punktu widzenia, uwzględniając etiologię i charakter przebiegu - na postępujące i niepostępujące [5] (Ryc. 1). 


\section{HEMIATROFIA MÓZGU \\ - kliniczna klasyfikacja etiologiczna BRAIN HEMIATROPHY \\ -clinical etiological classification}

\begin{tabular}{|c|c|}
\hline $\begin{array}{l}\text { NIEPOSTĘPUJACA: } \\
\text { NON-PROGRESSIVE: } \\
\text { - } \quad \text { udary krwotoczne i niedokrwienne } \\
\text { (Z.Dyke-Davidoff-Masson) } \\
\text { - } \quad \text { urazy mózgu } \\
\text { - } \quad \text { napromieniowanie } \\
\text { - } \quad \text { infekcje w życiu płodowym (TORCH: } \\
\text { toksoplazmoza, ospa, różyczka, } \\
\text { cytomegalia, opryszczka) }\end{array}$ & $\begin{array}{l}\text { POSTĘPUJACA: } \\
\text { PROGRESSIVE: } \\
\text { - } \quad \text { Zespół Sturge-Webera } \\
\text { - } \quad \text { Zespół Haberlanda (ECCL) } \\
\text { - } \quad \text { Zespół Parry-Romberga } \\
\text { - } \quad \text { Zespół Rassmusena } \\
\text { - } \quad \text { Germinoma z towarzyszącą hemiatrofią } \\
\text { - } \quad \text { zózgu } \\
\text { - } \text { pospoły: połowiczy zanik- dystonia/pląsawica } \\
\text { Stan padaczkowy: zespół połowiczych } \\
\text { drgawek-połowiczego niedowładu- } \\
\text { padaczki }\end{array}$ \\
\hline
\end{tabular}

Ryc. 1. Zmodyfikowano na podstawie Tan AP, Wong YLJ, Lin BJ, Yong HRC, Mankad K. Clinico-radiological approach to cerebral hemiatrophy. Childs Nerv Syst. 2018 [5]

Fig. 1. Modified from Tan AP, Wong YLJ, Lin BJ, Yong HRC, Mankad K. Clinico-radiological approach to cerebral hemiatrophy. Childs Nerv Syst. 2018 [5]
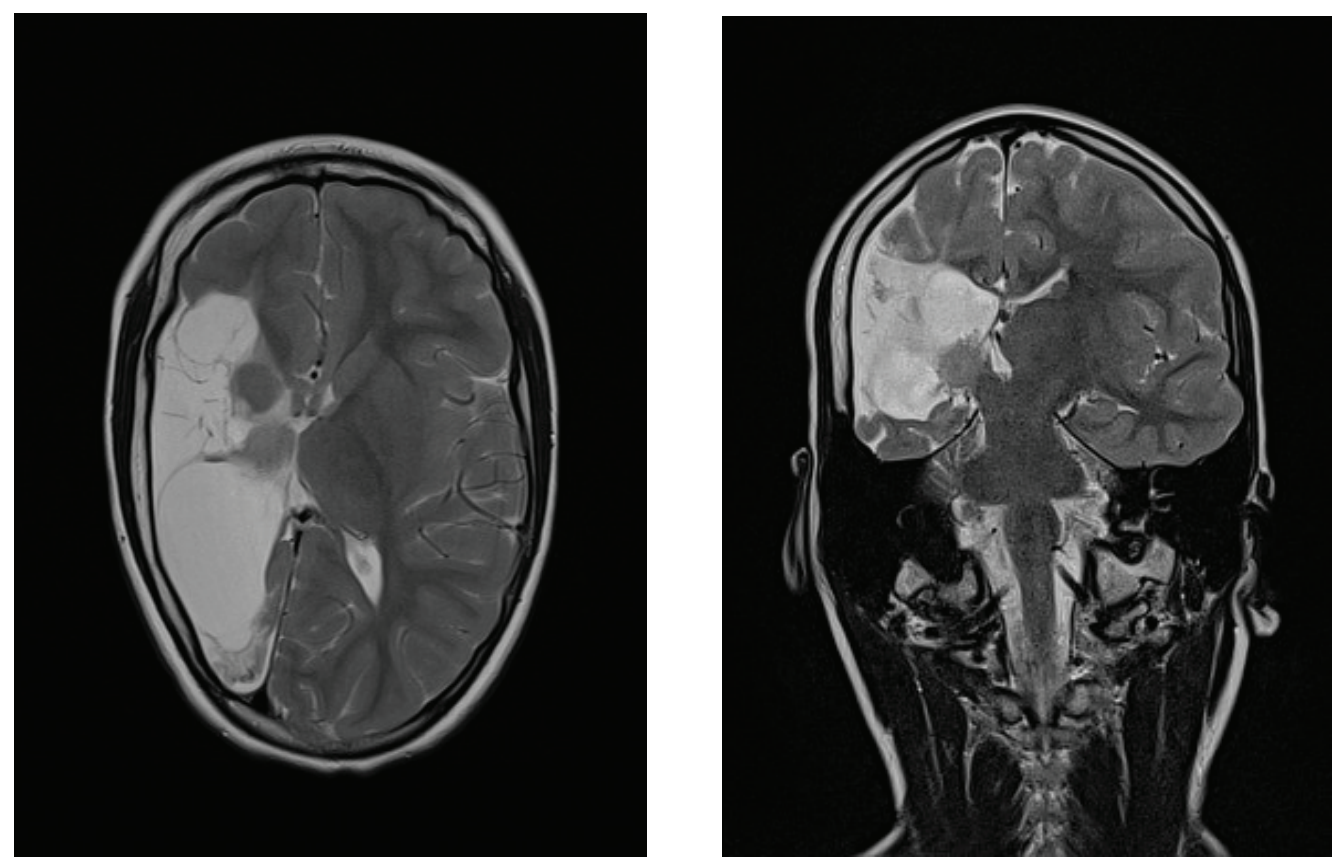

Ryc. 2. Chłopiec lat 8 z zespołem Dyke-Davidoff-Masson. Badanie MR mózgowia. Obrazy T2-zależne w płaszczyźnie poprzecznej i czołowej (A i B) - częściowa atrofia prawej półkuli mózgu ze zmianami bliznowato-malacyjnymi w obszarze unaczynienia tętnicy środkowej mózgu prawej (zdjęcie ze zbiorów Kliniki Neurologii Wieku Rozwojowego UM w Poznaniu).

Fig. 2. An 8- year-old boy with Dyke-Davidoff-Masson syndrome. MRI of the brain.T2-weighted images in the transverse and frontal planes (A and $B)$ - partial atrophy of the right hemisphere of the brain with scar-malformations in the area of the vascularization of the right middle cerebral artery (photo from the collection of the Department of Developmental Neurology, Medical University in Poznan). 
Do niepostępujących schorzeń, poza przypadkami związanymi z napromieniowaniem, urazami i infekcjami w życiu płodowym (najczęściej TORCH), zalicza się incydenty naczyniowe, a wśród nich zespół Dyke-Davidoff-Masson (Ryc.2). Jest to jednostka o charakterystycznym obrazie radiologicznym i klinicznym. W badaniach obrazowych stwierdza się częściową atrofię jednej z półkul mózgu będącą konsekwencją udaru w obrębie unaczynienia tętnicy środkowej mózgu, kompensacyjny przerost kości pokrywy czaszki, nadmierne upowietrznienie zatok przynosowych oraz komórek sitowych po stronie zawału mózgu [5, 8-11]. Pacjenci z tym schorzeniem, mają asy- metrię twarzy i głowy, lekooporną padaczkę, niedowład połowiczy oraz niepełnosprawność intelektualną [9-11]. Etiologia zespołu Dyke-Davidoff-Masson'a jest nieznana [5]. Zaobserwowano, że dochodzi do okluzji tętnicy środkowej mózgu na wczesnym etapie rozwoju układu nerwowego [11], w niepoznanym dotychczas mechanizmie. Większość przypadków opisywanych w literaturze dotyczy dzieci $[9,12]$ ale spotyka się również opisy nastolatków [10, 11], rzadziej dorosłych [11]. Napady padaczkowe, trudne do leczenia, niekiedy wymagają leczenia operacyjnego (hemisferektomii)[13].
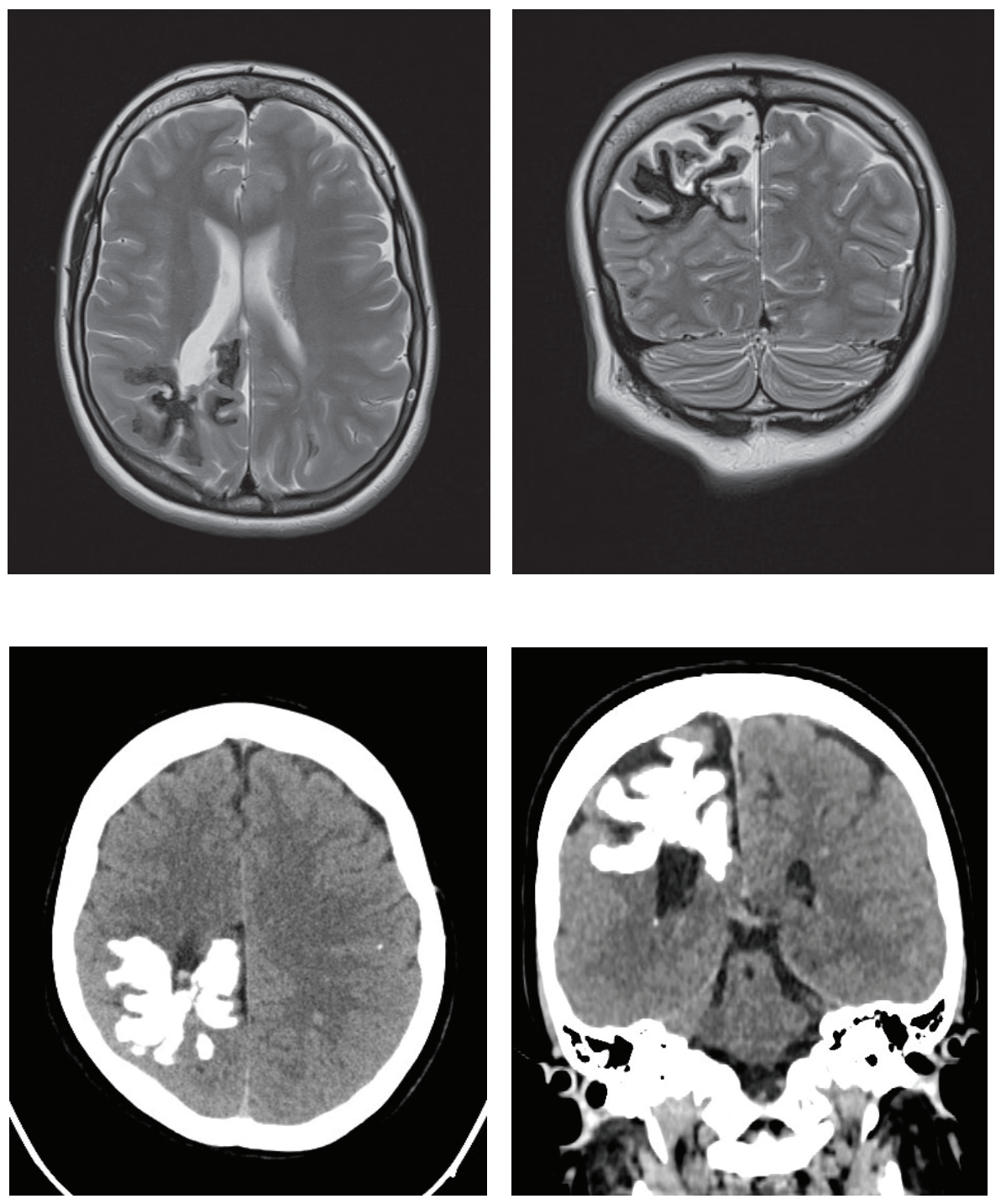

Ryc. 3. Dziewczynka lat 16 z zespołem Sturge-Weber'a.

A i B. Obrazy MR T2 zależne w płaszczyźnie poprzecznej i czołowej - zmniejszenie objętość płata ciemieniowego prawego z masywnymi zwapnieniami podkorowymi i towarzyszącym poszerzeniem przestrzeni podpajęczynówkowej w okolicy ciemieniowej prawej.

C i D. Obrazy TK w płaszczyźnie poprzecznej i czołowej - masywne, bezpostaciowe zwapnienia w prawym płacie ciemieniowym (zdjęcia ze zbiorów Kliniki Neurologii Wieku Rozwojowego UM w Poznaniu).

Fig. 3. A 16 -year -old girl with Sturge-Weber syndrome.

$A$ and $B$. T2-weighted images in the transverse and frontal planes - reduction in the volume of the right parietal lobe with massive subcortical calcifications and accompanying expansion of the subarachnoid space in the right parietal area. $C$ and D. CT images in the transverse and frontal planes - massive, amorphous calcifications in the right parietal lobe (photos from the collection of the Department of Developmental Neurology, Medical University in Poznan). 
Zespół Struge-Weber'a, naczyniakowatość twarzowomózgowa, zaliczający się do postępujących hemiatrofii mózgu, jest wrodzonym schorzeniem skórno-nerwowym, jedną z fakomatoz.

Jednostka ta obejmuje triadę objawów [14]:

- naczyniak płaski twarzy (,,port-wine stain”) widoczny od urodzenia, w obszarze unerwienia pierwszej gałęzi nerwu trójdzielnego,

- naczyniakowatość opon mózgowo-rdzeniowych, najczęściej jednostronna, tożstronna do naczyniaka twarzy, w okolicy ciemieniowo - potylicznej,

- jaskra, po stronie naczyniaka.

W zależności od konfiguracji powyższych cech, wyróżniamy 3 typy [14]:

I - klasyczny, naczyniak twarzy i opon, niekiedy obecna jaskra

II - naczyniak twarzy, bez zajęcia układy nerwowego, może wystąpić jaskra

III - tylko naczyniakowatość opon.

Zespół Struge-Weber’a ma podłoże genetyczne. Mutacja dotyczy genu GNAQ na chromosomie 9q21 i prowadzi do nieprawidłowego rozwoju układu naczyniowego, przetrwania splotów naczyniówkowych w pobliżu cewy nerwowej podczas życia zarodkowego [5, 14]. Badania obrazowe (Ryc.3), poza naczyniakowatością obecną w tylnych płatach, pokazują:

- mniejszą objętość zajętej półkuli mózgu,

- zwapnienia korowo-podkorowe (prawdopodobnie jako następstwo przewlekłych zmian niedokrwiennych) dające obraz „trakcji tramwajowej” w badaniach RTG i TK, a także szerokie spektrum nieprawidłowości rozwojowych kory mózgowej (drobnozakrętowość, dysplazje korowe, szczelinowatość mózgu) [5, 14].

Neurologicznie zespół Struge-Weber'a objawia się jako napady padaczkowe, opóźnienie rozwoju intelektualnego, zaburzenia zachowania, bóle głowy, incydenty naczyniowe oraz niedowłady połowicze [14]. Ze względu na nawracający i niekiedy przewlekły charakter epizodów niedokrwiennych w profilaktyce zakrzepowej i zastoju żylnego, stosuje się w niskich dawkach aspirynę [14].

Zespół Haberlanda, tłuszczakowatość mózgowo-czaszkowo-skórna (ECCL Encephhalocraniocutaneoous Lipomatosis) Ryc. 4 to jedna z rzadkich przyczyn postępujących hemiatrofii mózgu. Klasycznie zespół zajmuje skórę, gałkę oczną oraz ośrodkowy układ nerwowy [15]. Na skórze głowy, brzegach powiek i w gałce ocznej występują wypełnione tkanką tłuszczową hamartoma, natomiast w mózgu stwierdza się jamy porencefaliczne i tłuszczaki [15]. W badaniach obrazowych spotyka się: poszerzenie układu komorowego, poszerzenie przestrzeni podpajęczynówkowych, torbiele pajęczynówki, naczyniakowatość opon, zwapnienia i dysplazje korowe [15]. Neurologiczne symptomy to opóźnienie rozwoju psychoruchowego, upośledzenie umysłowe, napady padaczkowe i spastyczność przeciwległych kończyn. Bardzo typowe w zespole Haberlanda są zmiany dermatologiczne tzw. psiloliparus - miejsca na skórze głowy, pozbawione owłosienia, wypełnione tłuszczem [15]. Etiologia schorzenia nie jest do końca po- znana, prawdopodobnie dochodzi do postzygotycznej mutacji i zaburzeń rozwoju embrionalnego. Leczenie jest wyłącznie objawowe [15].
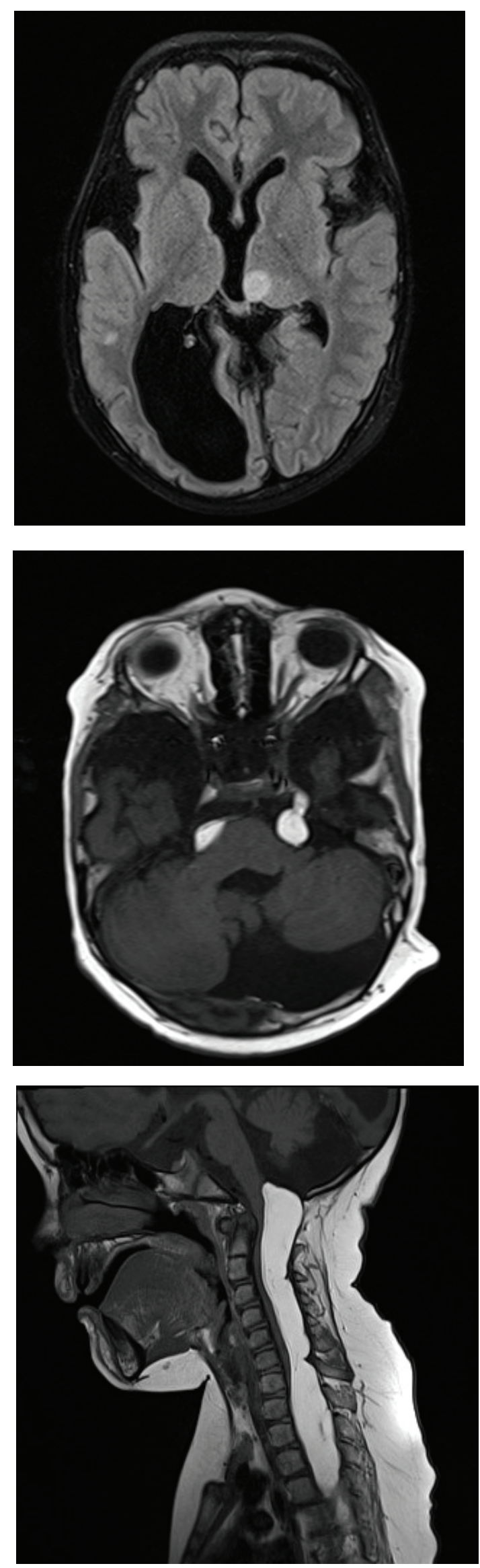


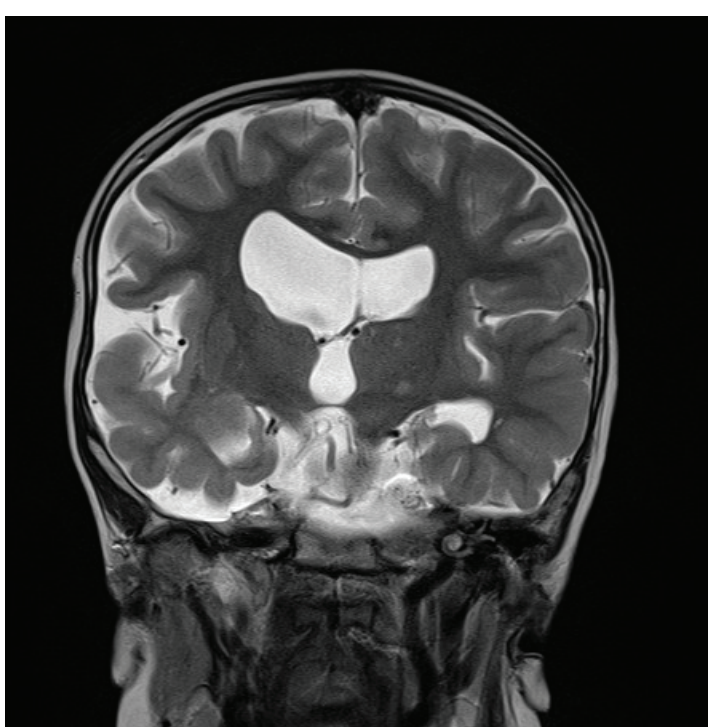

Ryc. 4. Badanie MR mózgowia w zespole Haberlanda. A. Obraz FLAIR w płaszczyźnie poprzecznej- ognisko hamartoma w lewym wzgórzu, poszerzenie szczeliny Sylwiusza po stronie prawej, znacznego stopnia asymetryczne poszerzenie rogu tylnego komory bocznej prawej.

B. Obraz T1-zależny w płaszczyźnie poprzecznej - duża torbiel pajęczynówki w tylnym dole czaszki po stronie lewej, poszerzenie przestrzeni podpajęczynówkowej obustronnie w przednich partiach środkowego dołu czaszki.

C. Obraz T1-zależny kręgosłupa szyjnego w płaszczyźnie strzałkowej - nieregularnego kształtu tłuszczak wypełniający światło kanału kręgowego od poziomu otworu wielkiego ku dołowi do poziomu kręgu Th4.

D. Obraz T2-zależny mózgowia w płaszczyźnie czołowej zmniejszenie objętości prawej półkuli mózgu, z asymetrycznie poszerzonym rogiem przednim komory bocznej prawej i poszerzeniem przestrzeni podpajęczynówkowej w środkowym dole czaszki po stronie prawej (zdjęcia ze zbiorów Kliniki Neurologii Wieku Rozwojowego UM w Poznaniu).

Fig. 4. MRI of the brain in Haberland syndrome.

A. Image of FLAIR in the transverse plane - hamartoma focus in the left thalamus, widening of Sylvian fissure on the right side, significant asymmetric widening of the posterior horn of the right lateral ventricle.

$B$. T1-weighted image in the transverse plane - large arachnoid cyst in the left posterior cranial fossa, widening of the subarachnoid space bilaterally in the anterior parts of the medial cranial fossa.

C. T1-weighted image of the cervical spine in the sagittal plane - an irregular lipoma filling the lumen of the spinal canal from the level of the great foramen downwards to the level of the Th4 vertebra.

D. T2-weighted image of the brain in the frontal plane a reduction in the volume of the right hemisphere of the brain, with an asymmetrically dilated anterior horn of the right lateral ventricle and a widening of the subarachnoid space in the middle cranial fossa on the right (photos from the collection of the Department of Developmental Neurology, Medical University in Poznan).
Zespół Parry-Romberg'a to kolejna rzadka jednostka, objawiająca się postępującym zanikiem skóry, tkanki podskórnej, mięśni i kości połowy twarzy $[5,16]$. Początkowe symptomy ujawniają się w pierwszej lub drugiej dekadzie życia [5]. Najczęstszą manifestacją neurologiczną jest padaczka ogniskowa, ale pacjenci zgłaszają również zaburzenia widzenia, objawy neuralgii nerwu trójdzielnego, migrenowe bóle głowy, niedowład nerwu twarzowego i zaburzenia funkcji poznawczych $[5,16]$. W badaniach obrazowych, tożstronnie do zaniku tkanek twarzy, opisywane są: podkorowe zwapnienia, zmiany w istocie białej (hipodensyjne w TK, hyperintenstywne w sekwencjach MR T2-zależnych) oraz zmniejszenie objętości półkuli mózgu, rzadziej odcinkowe pogrubienie opon czy korowa dysplazja $[5,16]$. Przyczyna tego schorzenia nie została ustalona. Z uwagi na kliniczne podobieństwa (objawy i zmiany radiologiczne) do miejscowej twardziny linijnej, typu „cięcia szablą” (,en coupe de sabre”) coraz częściej podaje się czynnik autoimmunologiczny [5, 16]. Rozważa się również zespół Parry Romberga, jako przynależny do spektrum twardziny miejscowej [5].

Zespół Rassmusena, inaczej zapalenie mózgu Rassmusena, charakteryzuje się przewlekłym stanem zapalnym jednej półkuli mózgu (głównie kory mózgowej), padaczką lekooporną oraz postępującymi niedowładem i zaburzeniami funkcji poznawczych $[17,18]$. Schorzenie to dotyczy populacji dziecięcej i młodych dorosłych, ze średnim wiekiem występowania w 6 roku życia. Typowe, klasyczne zapalenie przebiega w 3 fazach $[17,18]$ :

- Okres prodromalny - objawy niespecyficzne, rzadkie napady, niewielki niedowład połowiczy

- $\quad$ Okres ostry - częste napady padaczkowe (w 50\% przypadków występuje padaczka częściowa ciągła), postępujące deficyty neurologicznie: niedowład połowiczy, niedowidzenie połowicze, zaburzenia mowy, regres intelektualny

- Okres rezydualny - utrwalony niedowład, utrzymują się napady padaczkowe.

W neuroobrazowaniu, po kilku miesiącach od pierwszych objawów, mogą występować poszerzenie układu komorowego oraz nieostro ograniczone obszary hiperintensywne na obrazach MR T2-zależnych i FLAIR - w okolicy bruzdy Sylwiusza, obejmujące korę mózgową i podkorowo istotę białą (Ryc.5 i 6). W pierwszym etapie możliwy jest również zanik głowy jądra ogoniastego [5, 17, 18]. W ciągu kolejnych miesięcy postępuje atrofia całej półkuli mózgu, największa utrata objętości jest opisywana w pierwszych ośmiu miesiącach choroby $[17,18]$. Zmiany rejestrowane w EEG nie są specyficzne, początkowo może być zapis prawidłowy, z czasem nad zajętą półkulą opisuje się międzynapadową wysokonapięciową czynność wolną - delta oraz występują grafoelementy typowe dla czynności napadowej [17, 18] (Ryc.7). Przyczyną zespołu jest prawdopodobnie reakcja immunologiczna, w której biorą udział limfocyty cytotoksyczne T i komórki mikrogleju, prowadzące do stanu zapalnego kory, utraty neuronów i gliozy [17]. Leczenie zespołu Rassmusena ma na celu zwalczanie procesu zapalnego poprzez immunoterapię 
(sterydy, immunoglobuliny, plazmafereza, immunoadsorbcja białka A IgG, takrolimus, azatiopryna) [17, 18], a także opanowanie napadów padaczkowych poprzez zastosowanie leków przeciwpadaczkowych i leczenia operacyjnego, polegającego na hemisferectomii lub hemisferotomii [19].

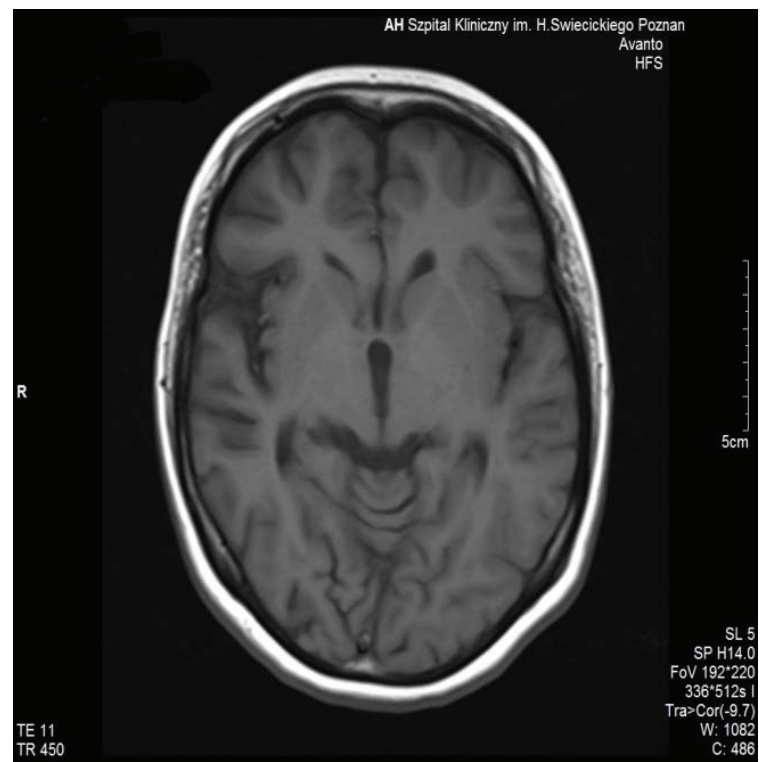

Postępowanie chirurgiczne w ok.70-80\% czyni pacjentów wolnymi od napadów [20]. W terapii, stosuje się również iniekcje toksyny botulinowej w grupy mięśniowe, objęte ciągłymi wyładowaniami [17].

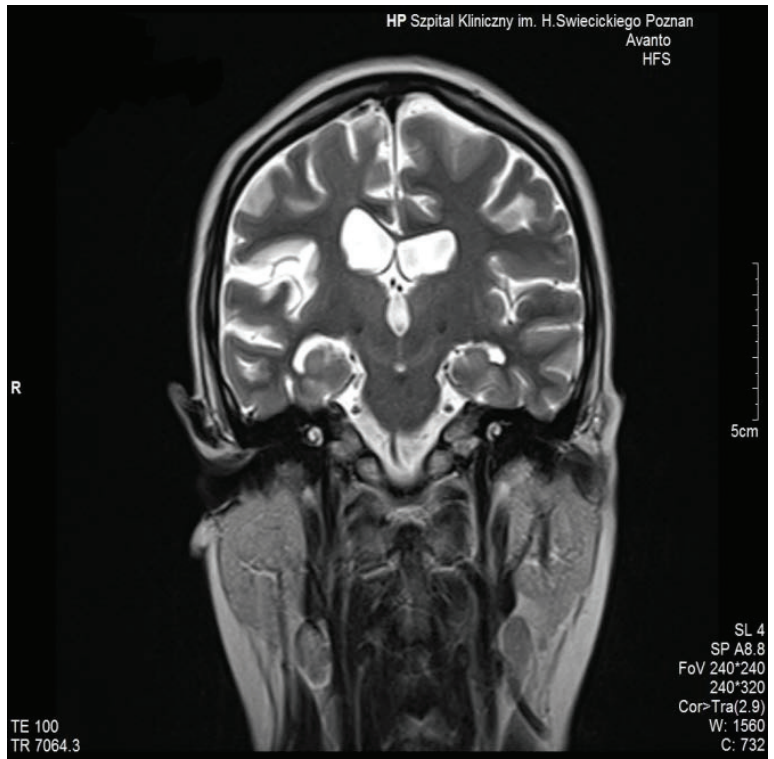

Ryc. 5. Dziewczynka lat 16 z zespołem Rassmusena.

- $\quad$ Obraz MR T1-zależny w płaszczyźnie poprzecznej - asymetryczne poszerzenie szczeliny Sylwiusza po stronie prawej.

- $\quad$ Obraz MR T2-zależny w płaszczyźnie czołowej - asymetryczne poszerzenie rogów przednich obu komór bocznych (w większym stopniu po stronie prawej) oraz poszerzenie szczeliny Sylwiusza po stronie prawej.

Fig. 5. A 16-year-old girl with Rassmusen syndrome.

- $\quad$ T1-weighted MR image in the transverse plane - asymmetric widening of the Sylvian fissure on the right side.

- $\quad$ T2 weighted MRI image in the frontal plane - asymmetrical widening of the anterior horns of both lateral ventricles (to a greater extent on the right side) and widening of the Sylvian fissure on the right side.

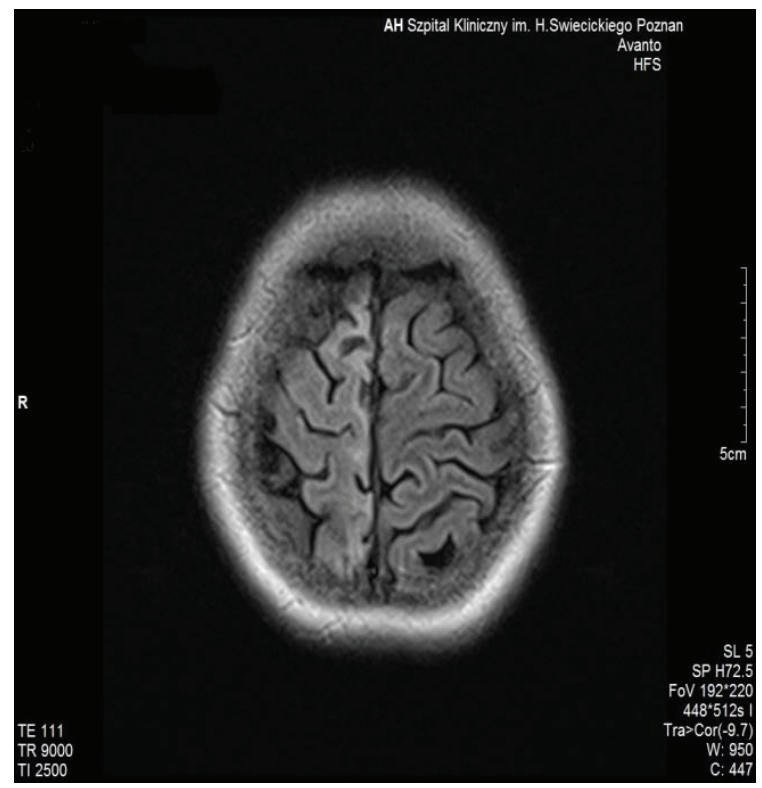

Ryc. 6. Ta sama dziewczynka lat 16 z zespołem Rassmusena. Obraz MR FLAIR w płaszczyźnie poprzecznej- korowo/ podkorowe, nieostro ograniczone obszary hiperintensywne w przystrzałkowych, wysokich partiach płatów czołowego i ciemieniowego prawego (zdjęcia ze zbiorów Kliniki Neurologii Wieku Rozwojowego UM w Poznaniu).

Fig. 6. The same 16-year-old girl with Rassmusen syndrome. FLAIR MR image in the transverse / subcortical plane, nonsharply limited hyperintensive areas in the supra-sagittal, high parts of the right frontal and parietal lobes (photos from the collection of the Department of Developmental Neurology, Medical University in Poznan). 

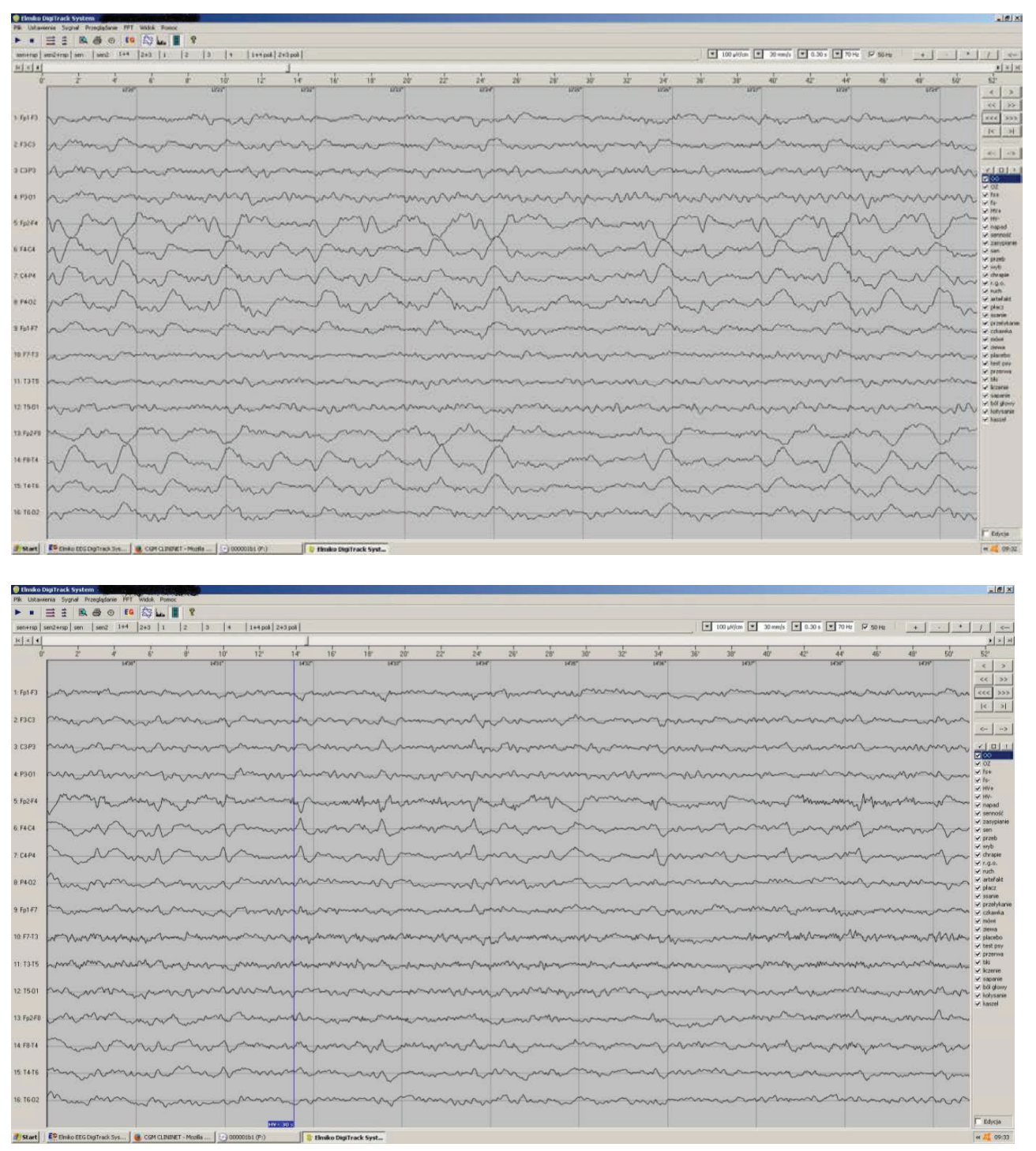

Ryc. 7. Zespoły fala ostra z falą wolną, fale wolne theta i delta w odprowadzeniach z prawej pótkuli u 16-letniej dziewczynki z zespołem Rassmusena (zapis ze zbiorów Kliniki Neurologii Wieku Rozwojowego UM w Poznaniu)

Fig. 7. Sharp wave with slow wave syndromes, slow theta and delta in the right hemisphere leads in a 16-year-old girl with Rassmusen syndrome (record from the collection of the Department of Developmental Neurology, Medical University in Poznan)

Zespól polowiczych drgawek, polowiczego niedowladu - padaczki, tzw. HHES (hemiconvulsion-hemiplegia-epilepsy syndrome) to jednostka, w której podczas infekcji z gorączką występują napady padaczkowe, klonie, najczęściej jednostronne, a następnie stwierdza się niedowład/porażenie po stronie drgawek. Zespół dotyczy dzieci do lat 4 [21]. Napady spełniają określone kryteria [21]:

- trwają kilka godzin, niekiedy powyżej doby

- $\quad$ występują w różnej lokalizacji, przy przedłużających się mogą rozwinąc się po przeciwległej stronie

- zmienny jest stopień zaburzeń świadomości

- różnorodny początek: ze zwrotem głowy/oczu, jednostronne lub obustronne drgawki z ewolucją do jednostronnych,

- możliwe wystąpienie objawów autonomicznych: nadmierne ślinienie się, zaburzenia oddychania, sinica.

W badaniach MR mózgowia najwcześniej występują cytotoksyczne, położone podkorowo obszary obrzęko- we $\mathrm{w}$ istocie białej. Od zmian niedokrwiennych odróżniają się odmienną lokalizacją (zmiany obrzękowe nie występują $\mathrm{w}$ zdefiniowanych obszarach zaopatrywania $\mathrm{w}$ krew przez główne wewnątrzczaszkowe pnie tętnicze) [5, 21, 22]. Po kilku tygodniach, zmiany obrzękowe ewoluują do hemiatrofii [5, 21, 22]. Przyczyna HHES jest nieznana [21], bierze się pod uwagę czynnik wirusowy: herpesvirus 7 , varicella zoster [23] lub pierwotnie łagodną malformację korową $[22,23]$. Genetycznie zespół jest prawdopodobnie związany z mutacjami w genie CACNA1A [19, 20]. HHES może być częścią większej grupy [21], do której przynależy FIRES (Fever Induced Refraktory Encephalopathy In School Aged Children) oraz NORSE (New Onset Refraktory Status Epilepticus), z tą różnicą, że każdy z wymienionych zespołów dotyczy mózgu na innym etapie dojrzewania. W celu opanowania napadów i zatrzymania uszkodzenia neuronalnego, w leczeniu HHES stosuje się leki przeciwpadaczkowe, przeciwobrzękowe i antagonistów receptorów NMDA [21]. U 2/3 pacjentów, po kilkutygodniowym okresie wolnym od 
napadów padaczkowych, rozwija się padaczka. Deficyt ruchowy, w miarę rehabilitacji może ustąpić. U części chorych pozostaje jednak znaczny niedowład [21].

Inną przyczyną hemiatrofii, mogą być procesy rozrostowe z grupy nowotworów zarodkowych [5]. Wewnątrzczaszkowe rozrodezaki (germinoma) to ok $0.5-2.1 \%$ wszystkich guzów wewnątrzczaszkowych [5]. Większość z tych guzów, dotyczy linii środkowej i zlokalizowane są przede wszystkim w szyszynce i okolicy nadsiodłowej. Znacznie rzadziej, bo tylko w ok. 5-10\% w jądrach podstawy i wzgórzu [5]. W początkowych stadiach, nowotwory zarodkowe powodują tylko subtelne zmiany intensywności sygnału w badaniach rezonansu magnetycznego. Wraz ze wzrostem objętości masy guza, w jego obrębie pojawiają się przestrzenie płynowe, z niekiedy występującymi objawami przebytego mikrokrwawienia, następnie stopniowo rozpoczyna się zanik zajętej półkuli [5]. Jako przyczynę atrofii uważa się zajęcie przez guz dróg z gęstymi włóknami, obecnych w torebce wewnętrznej $[5,24]$. W późniejszych stadiach dominuje komponenta torbielowata. Pojawia się efekt masy nasilony dodatkowo przez krwawienia do guza zarodkowego [5]. Jednostronny zanik w jądrach podstawy, wzgórzu lub w pniu mózgu to dość wczesny objaw radiologiczny rozwijającego się germinoma. Objawy kliniczne wynikają przed wszystkich z zajęcia włókien torebki wewnętrznej i są to przeciwstronne niedowłady oraz zaburzenia układu pozapiramidowowego (sztywność, drżenie, spowolnienie). Rzadziej są to objawy typowe dla lokalizacji okołosiodłowej germinoma (zaburzenia hormonalne - moczówka prosta, objawy gałkoruchowe) [24]. Bardzo rzadko występują czkawka i wymioty [6, 24], wynikające prawdopodobnie z zajęcia rdzenia przedłużonego. Jako leczenie, w zależności od lokalizacji i stopnia zaawansowania, stosowane są zabiegi chirurgiczne, chemioterapia $\mathrm{i} / \mathrm{lub}$ radioterapia $[24,25]$.

Wśród pacjentów dorosłych, zespoły z asymetrią mózgu prezentują nieco inne objawy kliniczne. Opisywane są przypadki zaburzeń ruchowych związanych z połowiczym zanikiem mózgu: hemiparkinsonizm-hemiatrofia (HPHA), hemidystonia-hemiatrofia i najrzadziej hemipląsawica-hemiatrofia. Etiologia tego schorzenia jest niepoznana. Rozpatruje się czynniki okołoporodowe oraz urazy głowy we wczesnym dzieciństwie $[6,7,26]$. Pierwsze symptomy mogą pojawiać się w czwartej lub w piątej dekadzie życia [7] i zazwyczaj poza sztywnością, spowolnieniem ruchowym, dystonią, obserwuje się zaburzenia neuropsychiatryczne [6] (zmienność nastroju, anhedonię, drażliwość, apatię, niekiedy zaburzenia psychotyczne). Zauważalna jest również asymetria kończyn i twarzy [7]. Postęp choroby jest powolny [6, 7]. Występuje zmienna odpowiedź na leczenie dopaminergiczne $[6,7,26]$. W badaniach obrazowych, w około $30 \%$ [7], opisywany jest zanik półkuli mózgu o różnym stopniu nasilenia. Mogą również występować zmiany ogniskowe i nieostro ograniczone obszary o nieprawidłowej intensywności sygnału w jądrach podstawy i korze mózgowej $[6,7]$.

W klasyfikacji radiologicznej odrębną grupą związaną z asymetrię mózgu, są wady rozwojowe kory mózgowej
[8]. Mogą być wynikiem mutacji genetycznych, zaburzeń naczyniowych, metabolicznych, infekcji oraz urazów [28]. W przypadku zaburzeń migracji neuroblastów dochodzi do redukcji objętości półkuli, czyli tzw. hemimicrencefalii lub wzrostu objętości - hemimegalencefalii.

Hemimicrencefalię obserwuję się w [8]:

- $\quad$ Polymicrogyrii (drobnozakrętowość) Ryc.8

- Hetrotypiach istoty szarej (guzki podkorowe)

- Szczelinie mózgu (schizencefalia)

- Pachygyrii (szerokozakrętowości) Ryc.9
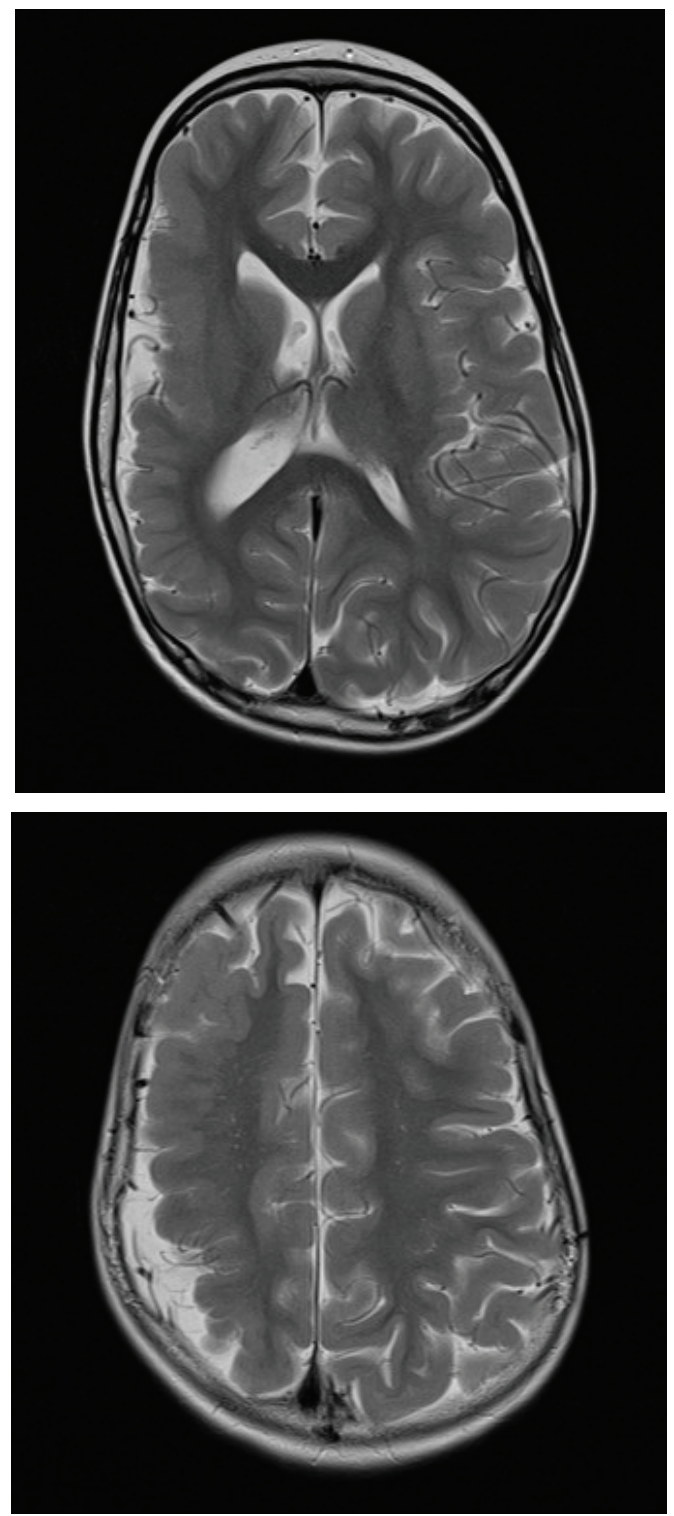

Ryc. 8. Chłopiec lat 7 z drobnozakrętowością i hemiplazją/ hemimicroencefalią

Obrazy MR FLAIR w płaszczyźnie poprzecznej (A i B).

Drobonozakrętowość w płatach czołowym i ciemieniowym prawej półkuli mózgu, z towarzyszącym asymetrycznym, niewielkiego stopnia poszarzeniem komory bocznej prawej i miernym poszerzeniem przestrzeni podpajęczynówkowej na sklepistości prawej półkuli mózgu (zdjęcia ze zbiorów Kliniki Neurologii Wieku Rozwojowego UM w Poznaniu)

Fig. 8. A 7-year-old boy with polimicrogyria and hemiplasia / hemimicroencephaly. 
MR FLAIR images in the transverse plane ( $A$ and $B)$. Minorotorism in the frontal and parietal lobes of the right cerebral hemisphere, accompanied by a slight asymmetrical graying of the right lateral ventricle and a moderate expansion of the subarachnoid space on the vault of the right cerebral hemisphere (photos from the collection of the Department of Developmental Neurology, Medical University in Poznan).
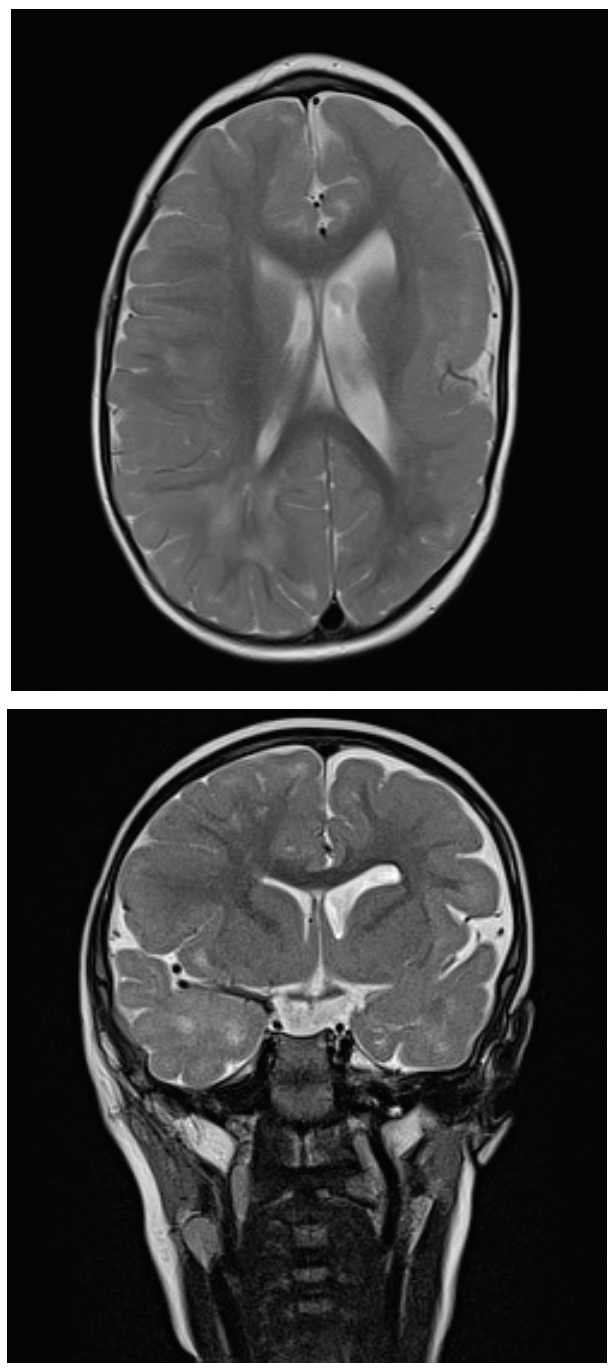

Ryc. 9. Chłopiec lat 2 z szerokozakrętowością i hemiaplazją prawej półkuli mózgu po przebytej w życiu płodowym infekcji CMV. A i B. Obrazy MR T2-zależne w płaszczyźnie poprzecznej i czołowej - szerokie, grube i spłaszczone zakręty kory mózgowej w płatach czołowym i ciemieniowym lewej półkuli z towarzyszącym, niewielkim poszerzeniem światła komory bocznej lewej i poszerzeniem przestrzeni podpajęczynówkowej na sklepistości lewej półkuli mózgu (zdjęcia ze zbiorów Kliniki Neurologii Wieku Rozwojowego UM w Poznaniu).

Fig. 9. A 2-year-old boy with broad rotoriasis and hemiaplasia of the right hemisphere of the brain after CMV infection in utero.

$A$ and $B$. T2-weighted MRI images in the transverse and frontal planes - wide, thick and flattened gyruses of the cerebral cortex in the frontal and parietal lobes of the left hemisphere with an accompanying slight widening of the left lateral ventricle and a widening of the subarachnoid space on the vault of the left hemisphere of the brain (photos from the collection of the Department of Developmental Neurology, Medical University in Poznan).

W przeglądzie literatury nie znajduje się przypadków izolowanej hemimicrencefalii. Najczęściej opisuję się ją w skojarzeniu z hemimegalencefalią drugiej półkuli [29, 30]. Prawdopodobnie (według autora) hemimicrencefalia nakłada się z zespołami, w których obok wady rozwojowej kory występuje hemiatrofia mózgu, tak jak w przypadku zespołów: Sturge-Webera, Haberlanda czy malformacjach związanych z infekcją w życiu płodowym. Możliwie z tego powodu nie jest wyodrębniana w piśmiennictwie.

Hemimegalencefalia może natomiast występować jako [31, 32]:

- wada izolowana, występująca sporadycznie, bez innych objawów towarzyszących skojarzona $\mathrm{z}$ innymi objawami, najczęściej w zespołach nerwowoskórnych, uwarunkowanych genetycznie (zespoły nerwowo skórne omówiono w tab.I)

- tzw. hemimegalencefalia całkowita (totalna) najrzadziej występująca forma, opisana pierwszy raz w 1923r. przez Hallevordena obejmuje tożstronny do przerostu półkuli mózgu przerost móżdżku i pnia mózgu.

Niezależnie od formy, hemimegalencefalia ma wspólny obraz histologiczny, radiologiczny i kliniczny [31, 32]. Objawy hemimegalencefalii to najczęściej: napady padaczkowe, niedowłady przeciwległej strony, upośledzenie umysłowe [31, 32]. Ponadto obserwuje się: opóźnienie rozwoju, asymetrię głowy/twarzy, trudności z nauką, niedowidzenie jednostronne [31]. Obraz kliniczny może mieć różny stopień nasilenia w zależności o wielkości wady [31]. Zespoły skojarzone $\mathrm{z}$ hemimegalencefalią przedstawiono w tabeli I.

W badaniach obrazowych mózgu stwierdza się przede wszystkim (31): asymetrię z przerostem jednej półkuli oraz nieprawidłowy układ komorowy: poszerzony, wydłużony róg przedni komory bocznej i/lub colocephalię (poszerzenie światła rogu tylnego komory bocznej) [31].

Ponadto spotyka się [31] :

- „objaw potyliczny”, charakterystyczne dla hemimegalencefalii przesunięcie płata potylicznego dotkniętej półkuli w kierunku zdrowej

- $\quad$ asymetryczne lub zniekształcone ciało modzelowate

- dysplazje korowe i zmniejszenie różnicy intensywności sygnałów pomiędzy warstwą korową i istotą białą mózgowia.

- $\quad$ przerost istoty białej.

Histologicznie opisuje się zaburzoną architekturę kory (z nieprawidłowym podziałem na warstwy), komórki balonowate, duże neurony o nieprawidłowych kształtach i morfologii oraz „dziwaczny” rozplem komórek glejowych (31). 


\section{PODSUMOWANIE}

Zespoły związane $\mathrm{z}$ asymetrią mózgu mimo podobieństw w objawach klinicznych (zwłaszcza w populacji dziecięcej) są bardzo zróżnicowane. Ogromną rolę w ich diagnozowaniu i różnicowaniu pełnią badania obrazowe. W wykonywanych badaniach radiologicznych warto szczególnie zwracać uwagę na: zmiany w kościach czaszki, przemieszczenie sierpa mózgu, deformacje zakrętów mózgu, poszerzenie przestrzeni podpajęczynówkowych i zmiany w kształcie układu komorowego [8]. Są to bowiem cechy, nadające kierunek dalszej diagnostyce w celu ustalenia rozpoznania i określenia charakteru schorzenia (postępujące czy nie). Znajomość „typowych” objawów radiologicznych $\mathrm{w}$ połączeniu $\mathrm{z}$ manifestacją kliniczną, znacząco ułatwia różnicowanie, a następnie odpowiednie leczenie zespołów związanych z asymetrią mózgu.

Tab.I. Zespoły skojarzone z hemimegalencefalią:

Tab.I. Syndromes associated with hemimegalencephaly:

\begin{tabular}{|c|c|}
\hline \begin{tabular}{|l|} 
Zespół znamion naskórkowych \\
Epidermal nevus syndrome
\end{tabular} & $\begin{array}{l}\text { Występowanie znamion naskórkowych (linijnych łojotokowych, brodawkowatych, } \\
\text { linijno - zapalno - brodawkowatych) w ok. 50\% skojarzone z hemimegalencefalią, często } \\
\text { z towarzyszącym podskórnym połowiczym tłuszczakiem twarzy po stronie przerośniętej } \\
\text { półkuli. Powyższe objawy tworzą charakterystyczną dla zespołu triadę [31]. }\end{array}$ \\
\hline \begin{tabular}{|l|} 
Zespół Proteusza \\
Proteus syndrome
\end{tabular} & $\begin{array}{l}\text { Genetycznie uwarunkowane schorzenie związane najprawdopodobniej z mutacją } \\
\text { w onkogenie ATK1 [33]. Wada powstaje w życiu embrionalnym i dotyczy komórek } \\
\text { pochodzących z linii objętej mutacją [33]. Zespół ten charakteryzuje się nadmiernym } \\
\text { przerostem skóry, tkanki łącznej oraz mózgu. Dochodzi do rozrostu palców rąk i stóp, } \\
\text { nadmiernej pigmentacji skóry, wielu objawów neurologicznych: najczéściej opóźnienia } \\
\text { rozwoju psychoruchowego i padaczki, rzadziej zaburzeń chodu, drżenia rąk, bólu głowy, } \\
\text { zaburzeń napięcia mięśniowego [34]. Występują również wady serca, naczyń, płuc, } \\
\text { układu moczowo- płciowego [31]. }\end{array}$ \\
\hline \begin{tabular}{|l|} 
Zespół Klippel-Trénanay \\
Klippel-Trénanay syndrome
\end{tabular} & $\begin{array}{l}\text { To zespót, w którym występują malformacje naczyń żylnych, włosowatych i } \\
\text { limfatycznych, przerost tkanek miękkich i kości długich oraz niekiedy malformacje } \\
\text { limfatyczne [38]. Najprawdopodobniej wywołany przez mutację w genie PIK3CA[36]. } \\
\text { Obraz kliniczny jest zmienny w natężeniu objawów i poza manifestacjami } \\
\text { neurologicznymi (napady padaczkowe, bóle głowy, udary, malformacje naczyń } \\
\text { mózgowych, hemimegalencefalia[37]) mogą występować incydenty zatorowo- } \\
\text { zakrzepowe wymagające leczenie interwencyjnego[38]. }\end{array}$ \\
\hline \begin{tabular}{|l|} 
Hypomelanoza Ito \\
Ito hypomelanosis
\end{tabular} & $\begin{array}{l}\text { Fakomatoza, trzecia co do częstości występowania po neurofibromatozie typu I oraz } \\
\text { stwardnieniu guzowatym [35]. Charakteryzuje się smugowatymi, wirowatymi lub } \\
\text { wstęgowatymi odbarwieniami skóry kończyn i tułowia na przebiegu linii Blashko } \\
\text { (szlaki migracji melanocytów) [35]. Znamiona obecne od urodzenia lub od wczesnego } \\
\text { dzieciństwa, z wiekiem stają się bardziej wyraźne. Poza skórą schorzenie najczéściej } \\
\text { zajmuje układ nerwowy i mięśniowo- szkieletowy (skolioza, połowiczy przerost } \\
\text { ciała, asymetria kończyn, deformacje klatki piersiowej)[35]. Objawy neurologiczne } \\
\text { to padaczka i opóźnienie rozwoju psychoruchowego, związane najczęściej z wadami: } \\
\text { hemigelancefalią, makrocefalią, mikrocefalią lub aplazją ciała modzelowatego [35]. Mogą } \\
\text { również występować nieprawidłowości małżowin usznych, szorstkie włosy, a na dnie } \\
\text { oczu - ogniska pozbawione barwnika [18] }\end{array}$ \\
\hline \begin{tabular}{|l|} 
Neurofibromatoza typ I ( NF-1) \\
Type I neurofibromatosis (NF-1)
\end{tabular} & $\begin{array}{l}\text { To najczęstsza fakomatoza, o dziedziczeniu autosomalnie dominującym, związana } \\
\text { z mutacja genu NF-1 na chromosomie 17, którego produktem jest neurofibromina. } \\
\text { Pacjenci z tym schorzeniem mają wysoká predyspozycję do rozwoju nowotworów } \\
\text { tagodnych i złośliwych [40]. Objawy skórne to plamy „,café au lait”, piegowate } \\
\text { nakrapiania pach, guzki podskórne (nerwiaki i nerwiakowłókniaki), ponadto występują } \\
\text { guzy tęczówki tzw. guzki Lischa, nerwiakowłókniaki splotowate, nieprawidtowości } \\
\text { kostne, glejaki nerwów wzrokowych [18]. Z objawów neurologicznych pacjenci z } \\
\text { NF-1 mogą prezentować trudności szkolne, zaburzenia mowy, nadpobudliwość, może } \\
\text { występować padaczka i opóźnienie rozwoju umysłowego [18]. } \\
\text { Hemimegalencefalia w NF-1 występuje bardzo rzadko [31], częściej występuje } \\
\text { megalencefalia [31,42] }\end{array}$ \\
\hline
\end{tabular}




\begin{tabular}{|l|l|}
\hline Stwardnienie guzowate & Schorzenie nerwowo - skórne, uwarunkowane genetycznie, związane z mutacją genu \\
Choroba Bournevillea,a, choroba & TSC1(na chromosomie 9)lub TSC 2(na chromosomie 16), o dziedziczeniu autosomalnie \\
Bourneville'a-Pringle'a & dominującym i zmiennej ekspresji [18]. Objawy kliniczne [18] są związane z zajęciem \\
Tuberous sclerosis & skóry, układu nerwowego i narządów. Zajęcie skóry (obecne w 90\% przypadków) \\
Bourneville disease, Bourneville- & manifestuje się w postaci plam odbarwieniowych, guzków angiofibroma (guzki Pringle'a \\
Pringle disease & na twarzy), płaskie włókniaki okolicy czołowej, włókniaki około paznokciowe). W mózgu \\
& występują guzki podwyściótkowe (w 90\%), rzadziej podwyściótkowy gwiaździak \\
& olbrzymiokomórkowy. Objawy neurologiczne to napady padaczkowe, opóźnienie rozwoju \\
& psychoruchowego i umystowego oraz objawy neuropsychiatryczne określane \\
& w piśmiennictwie jako TAND (tuberous sclerosis-associated neuropsychiatric \\
& disorder) [39]: zaburzenia funkcji poznawczych, zmienność nastroju, agresja, niepokój, \\
& depresyjność, zaburzenia snu i trudności \\
& w nauce. W innych narządach spotykane są: \\
& w sercu - guzy rhabdomyoma, w nerkach \\
& i w wątrobie - guzki angiomyolipoma, \\
& W gatce ocznej - guzki siatkówki [18]. \\
& W terapii guzów nerek i mózgu znajdują zastosowanie inhibitory szlaku mTOR \\
& (ewerolimus lub rapamycyna), leczenie przeciwpadaczkowe (wigabatryna, ACTH) \\
& wdraża się już w momencie zmian napadowych w EEG [18]. \\
\hline
\end{tabular}

\section{PIŚMIENNICTWO}

[1] Corballis M.C.: Evolution of cerebral asymmetry. Prog Brain Res.2019; 250: 153-178.

[2] Corballis M.C.: Häberling I.S.: The Many Sides of Hemispheric Asymmetry: A Selective Review and Outlook. J Int Neuropsychol Soc. 2017; 23: 710-718.

[3] Corballis M.C.: Early signs of brain asymmetry. Trends Cogn Sci. 2013; 17: 554-555.

[4] Schmitz J., Güntürkün 0., Ocklenburg S.: Building an Asymmetrical Brain: The Molecular Perspective. Front Psychol. 2019; 10: 982.

[5] Tan A.P., Wong Y.L.J., Lin B.J., et al.: Clinico-radiological approach to cerebral hemiatrophy. Childs Nerv Syst. 2018; 34: 2377-2390.

[6] Phi J.H., Cho B.K., Kim S.K., et al.: Germinomas in the basal ganglia: magnetic resonance imaging classification and the prognosis. $\mathrm{J}$ of Neurooncology. 2010; 99: 227-236.

[7] Reiter E., Heim B., Scherfler C., et al.: Clinical Heterogeneity in Cerebral Hemiatrophy Syndromes. Mov Disord Clin Pract. 2016; 3: 382-388.

[8] D'Apolito G., Calandrelli R., Caulo M., et al.: Brain asymmetry in Newborns: key findings, case series and literature review. Poster No.: C-1519 Congress: ECR $2015 \mathrm{G}$

[9] Abdul Rashid A.M., Md Noh M.S.F.: Dyke-Davidoff-Masson syndrome: a case report. BMC Neurol 2018, 18: 76.

[10] Li Y., Zhang T., Li B., et al.: A potential cause of adolescent onset DykeDavidoff-Masson syndrome: A case report. Medicine (Baltimore). 2019; 98: e18075.

[11] El Bahri-Ben Mrad F., Mrabet H., Ben Sghaier R., et al.: Syndrome de Dyke-Davidoff-Masson: a propos de deux observations [Dyke-DavidoffMasson syndrome: a report of two cases]. J Neuroradiol. 2005; 32: 5053.

[12] Gajewska E., Malak R., Kroll P., et al.: Rozwój motoryczny dziewczynki z ZDDM. Fizjoterapia polska nr 2/2013: 39-41.

[13] Alam M, Haq M, Ali F, et al.: Dyke-Davidoff-Masson Syndrome: An Unusual Cause of Status Epilepticus and Refractory Seizures. Journal of the College of Physicians and Surgeons-Pakistan : JCPSP. 2018 Jun; 28: 99-101.

[14] Pietrzak M., Kacprzak A., Mazur M., et al.: Zespół Sturge'a-Webera aktualne rekomendacje diagnostyczno-terapeutyczne. Neurol Dziec. 2016; 25, 50: 101-108.

[15] Özdoğan S., Saymaz C., Yaltırı C.K., et al. Encephalocraniocutaneous Lipomatosis: Haberland Syndrome. Am J Case Rep. 2017; 18: 12711275.

[16] Paprocka J., Jamroz E., Adamek D., et al.: Difficulties in differentiation of Parry-Romberg syndrome, unilateral facial sclerodermia, and Rasmussen syndrome. Childs Nerv Syst. 2006; 22: 409-415.
[17] Varadkar S., Bien C.G., Kruse C.A., et al. Rasmussen's encephalitis: clinical features, pathobiology, and treatment advances. Lancet Neurol. 2014; 13: 195-205.

[18] Steinborn B.[red.], Neurologia wieku rozwojowego. PZWL Warszawa 2017.

[19] Steinborn B.[red.], Neurologia dziecięca w przypadkach klinicznych. PZWL Warszawa 2018

[20] Hoffman C.E., Ochi A., Snead 0.C. 3rd, et al.: Rasmussen's encephalitis: advances in management and patient outcomes. Childs Nerv Syst. 2016; 32: 629-640.

[21] Sethi N.K., Tenney J.R.: Child Neurology: Hemiconvulsion-hemiplegiaepilepsy syndrome. Neurology. 2012; 79: 2367-2368.

[22] Auvin S., Bellavoine V., Merdariu D., et al.: Hemiconvulsion-hemiplegiaepilepsy syndrome: current understandings. Eur J Paediatr Neurol. 2012; 16: 413-421.

[23] Itamura S., Okanishi T., Arai Y., et al.: Three Cases of HemiconvulsionHemiplegia-Epilepsy Syndrome With Focal Cortical Dysplasia Type IIId. Front Neurol. 2019; 10: 1233.

[24] Konovalov A.N., Kadyrov S.U., Tarasova E.M., et al.: Basal ganglia germinomas in children. Four clinical cases and a literature review. Zh Vopr Neirokhir Im N N Burdenko. 2016; 80: 71-82.

[25] Wong T.T., Chen Y.W., Guo W.Y., et al.: Germinoma involving the basal ganglia in children. Childs Nerv Syst. 2008; 24: 71-78.

[26] Dziadkiewicz A., Białecka M., Janik P., et al.: Hemiparkinsonismhemiatrophy syndrome - report on two cases and review of the literature. Neurol Neurochir Pol. 2013; 47: 387-392.

[27] Ropper A. H, Samuels M. A., Klein J. P.: Adams and Vicor's Priniples of Neurology, 10th edition, Mc Graw Hill Education 2014.

[28] Steinborn B.[red.], Standardy postępowania diagnostycznoterapeutycznego w schorzeniach układu nerwowego u dzieci i młodzieży, Wydawnictwo Bifolium, Lublin 2013 p.25-35.

[29] Shiroishi M.S., Jackson H.A., Nelson M.D. Jr, et al.: Contralateral hemimicrencephaly in neonatal hemimegalencephaly. Pediatr Radiol. 2010; 40: 1826-1830.

[30] Salamon N., Andres M., Chute D.J., et al.: Contralateral hemimicrencephaly and clinical-pathological correlations in children with hemimegalencephaly. Brain. 2006; 129: 352-365.

[31] Flores-Sarnat L.: Hemimegalencephaly syndrome. Handb Clin Neurol. 2008; 87: 153-176.

[32] Bulteau Ch., Oliver M.V., Fohlen M.: Hémimégalencéphalie : aspects génétiques, cliniques et histologiques. Epilepsies. 2008; 20: 274-280.

[33] Lindhurst M.J., Sapp J.C., Teer J.K., et al.: A mosaic activating mutation in AKT1 associated with the Proteus syndrome. N Engl J Med. 2011; 365: 611-619. 
[34] Ogrodnik M.,Sadowski K., Jóźwiak S.: Neurological manifestations of Proteus syndrome - review of the literature. Neurol Dziec. 2015; 24: 47-53.

[35] Chamli A., Litaiem N.: Hypomelanosis of Ito. In: StatPearls [Internet] Treasure Island (FL): StatPearls Publishing; 2020 Jan

[36] John P.R.: Klippel-Trenaunay Syndrome. Tech Vasc Interv Radiol. 2019; 22: 100634.

[37] Jellouli 0., Dafiri R.: Syndrome de Klippel-Trenaunay associé à une hémimégalencéphalie [Klippel-Trenaunay syndrome associated with hemimegalencephaly]. Arch Pediatr. 2015; 22: 71-74.
[38] Fliciński J., Brylak J., Stański M., et al.: Klippel-Trenaunay Syndrome follow up - case report. Neurol Dziec. 2016; 25, 51: 67-74.

[39] Portocarrero L.K.L., Quental K.N., Samorano L.P., et al.: Tuberous sclerosis complex: review based on new diagnostic criteria. An Bras Dermatol. 2018; 93: 323-331.

[40] Hirbe A.C., Gutmann D.H.: Neurofibromatosis type 1: a multidisciplinary approach to care. Lancet Neurol. 2014; 13: 834-843.

[41] Cutting L.E., Cooper K.L., Koth C.W., et al.: Megalencephaly in NF1: predominantly white matter contribution and mitigation by ADHD. Neurology. 2002; 59: 1388-1394. 